\title{
Analysis of the chemerin and resistin adipokines in children and adolescents
}

\author{
(D) Vanessa S. Fontes ${ }^{1}$ \\ (iD) Kácia Mateus ${ }^{2}$ \\ (iD) Michele P. Netto ${ }^{3}$ \\ (iD) Renata M. S. Oliveira ${ }^{3}$ \\ Georae L. L. Machado-Coelho ${ }^{4}$ \\ (iD) Ana Paula C. Cândido
}

1.Doutoranda em Saúde Coletiva, Departamento de Nutrição, Instituto de Ciências Biológicas, Universidade Federal de Juiz de Fora, Juiz de F ora, MG, Brasil 2. Técnica em Nutrição, Departamento de Nutrição, Instituto de Ciências Biológicas, Universidade Federal de Juiz de Fora, Juiz de Fora, MG, Brasil 3. Docente, Departamento de Nutrição, Instituto de Ciências Biológicas, Universidade Federal de Juiz de Fora, Juiz de Fora, MG, Brasil

4. Docente, Escola de Medicina, Universidade Federal de Ouro Preto, Ouro Preto, MG, Brasil

http://dx.doi.org/10.1590/1806-9282.66.3.300

\section{SUMMARY}

OBJECTIVES: To compare the serum concentrations of adipokines resistin and chemerin in children and adolescents with eutrophic and overweight and to evaluate their relationship with anthropometric, biochemical, and blood pressure variables.

METHODS: a cross-sectional epidemiological study was conducted with 234 students enrolled in public elementary schools in the city of Juiz de Fora / MG. Anthropometric evaluation, biochemistry, and blood pressure measurement were performed. Statistical analyzes included the Student-t or Mann-Whitney tests, Pearson or Spearman correlation, used according to the distribution of the variables, and linear regression analysis, by means of the evaluation of the effect of the independent variables on the serum levels of chemerin and resistin, adjusted for age and sex. For the data analysis, SPSS ${ }^{\circledR}$ software version 21.0 and STATA ${ }^{\circledR}$ version 10.1 were used, assuming a significance level of $5 \%$.

RESULTS: the concentrations of chemerin were higher in eutrophic individuals than in those with excess weight ( $p>0.05$ ). In contrast, levels of resistin were higher in the young with excess weight than in the eutrophic ones $(p<0.05)$. In the multiple linear regression analysis, the levels of chemerin were associated with the values of resistin, systolic, and diastolic blood pressure. Resistance levels maintained association only with BMI and chemerin values.

CONCLUSION: the adipokines analyzed presented a distinct profile in the groups of children and adolescents with eutrophic and overweight. KEYWORDS: Child. Adolescent. Adipokines. Risk factors. Chemokines. Resistin.

\section{INTRODUCTION}

Although cardiovascular diseases (CVD) are rare in childhood, the atherosclerotic process begins during this stage and is characterized as an inflammatory disease of the blood vessel walls that triggers a series of responses, at the cellular and molecular level, which is intensified in individuals with obesity, since the adipose tissue is responsible for secreting numerous bioactive substances - the adipokines - that may have pro-inflammatory or anti-inflammatory action ${ }^{1}$.

The unregulated production of these substances, fostered by the increase in fat mass, can contribute to the onset of metabolic disorders resulting from obesity $^{2.3}$. Studies have reported that adipokines are related to excess weight, dyslipidemia, hypertension, 
and insulin resistance, both in adults and children and adolescents $^{4.5}$.

The marked presence of inflammatory markers associated with excess weight among children is worrying since long-term inflammation causes cumulative vascular damage, indicating a risk of future cardiovascular events ${ }^{6}$.

In the face of the alarming prevalence of excess weight among children and adolescents and its possible consequences in adulthood, it is important to better understand the physiopathology of the adipose tissue and the substances its secretes, investigating their association with the inflammatory process and its metabolic and cardiovascular implications. However, the literature on the role of adipokines in the children and adolescent population and their association with comorbidities and cardiometabolic risk variables is still scarce. Therefore, the objective of this study is to compare the serum concentrations of the resistin and chemerin adipokines in children and adolescents with eutrophy and excess weight and assess its relationship with anthropometric and biochemical variables and blood pressure, traditionally used to evaluate cardiovascular risk.

\section{METHODS}

\section{Study design and sampling process}

This is a cross-sectional epidemiological study conducted in the municipality of Juiz de Fora, MG, and divided into two stages. In the first stage, we evaluated a probability sample of 708 students from 7 to 14 years old of both sexes, enrolled in public schools of elementary education. The second stage involved a subsample of 234 students, randomly selected and divided into two groups based on their BMI classification, according to their age: (a) children and adolescents with eutrophy and (b) children and adolescents with excess weight.

We did not include in the sampling process students who attended Special Education classes and the adolescents who reported pregnancy. For the subsample, we excluded students with low weight.

The sample was selected through a simple random sampling process, according to age and proportion in each school. The sample size calculation was based on the proportion of the population studied with the prevalence of overweight and obesity for the age group studied (8\%), considering $20 \%$ of losses due to possible absences or refusals, a desired precision of $2 \%$, and a significance level of $5 \%$.

\section{Anthropometric assessment and body composition}

In the anthropometric analysis, we included weight, height, body fat percentage, and waist perimeter. The weight was measured by a digital electronic scale with bioelectrical impedance (Tanita Ironman ${ }^{\circledR}$ ), and the height was measured using a portable stadiometer (Alturexata ${ }^{\circledR}$ ).

The nutritional status of the students was determined by BMI, calculated by dividing the weight $(\mathrm{kg})$ by the squared height $\left(\mathrm{m}^{2}\right)$ and classified according to the BMI curve per age. To calculate the data, we used AnthroPlus ${ }^{\circledR}$ software.

The waist perimeter was measured using a simple inelastic measuring tape at the midpoint between the iliac crest and the costal arch.

The assessment of body composition, using horizontal tetrapolar bioelectrical impedance equipment (Biodynamics ${ }^{\circledR}$ ), was performed following the instructions of the equipment manufacturer. To determine the percentage of body fat, we used the equation by Deurenberg et al. ${ }^{7}$ based on the resistance and reactance values in relation to age.

\section{Measurement of pressure levels}

The blood pressure levels were measured three times, alternately, on the right arm, using a digital oscillometric sphygmomanometer $\left(\mathrm{Omron}^{\circledR}\right)$, with a cuff adjustable to the width of the arm. The minimum interval between measurements was 5 minutes.

\section{Biological samples and biochemical analyzes}

Blood samples were collected by venous puncture from the antecubital region of patients after 12 hours of fasting. The following biochemical analyses were carried out: (a) total cholesterol and ratios; (b) triglycerides; (c) serum glucose; and (d) insulin. All were measured by the enzymatic colorimetric method and adapted to the automatic analyzer Cobas Mira Plus ${ }^{\circledR}$.

Insulin resistance was determined by the HOMA-IR index (Homeostasis Model Assessment Insulin Resistance), using the formula Homa-IR= fasting insulin (IU/ $\mathrm{mL}) x$ fasting glycemia $(\mathrm{mmol} / \mathrm{l}) / 22.5$.

From the blood serum of the samples collected, three aliquots were obtained, which were placed in an amber tube, encoded, and stored at $-80^{\circ} \mathrm{C}$. The serum was used for the resistin and chemerin analyses by the immunoenzymatic ELISA method (Enzyme-Linked ImmunoSorbent Assay). For this purpose, commercial kits were used of the brands Sigma-Aldrich ${ }^{\circledR}$ 
(RAB0419) and Abcam's ${ }^{\circledR}$ (ab155430), respectively, following the protocol established by the manufacturers.

\section{Ethical aspects}

The legal guardians and principals of the schools were previously informed about the objectives, the protocol, and study procedures, as well as the risks and benefits of participating in the present study.

The student participation was voluntary, upon authorization and signing of the Informed Consent by parents and/or guardians. The study was approved by the Human Research Ethics Committee of the Federal University of Juiz de Fora - the first stage by decision No 09/2010 and the second by decision No $789.725 / 2014$.

\section{Statistical analysis}

Initially, we used the Kolmogorov-Smirnov test to verify if the distribution of the variables followed the assumptions of normality. In the descriptive analysis, we highlighted the measures of central tendency (mean or median) and their corresponding values of dispersion (standard deviation and interquartile range). Based on the distribution of the variables, we used the Student $t$-test or Mann-Whitney test to compare the mean values in each group and the Pearson or Spearman correlation tests for quantitative variables.

Multiple linear regression analysis was performed to assess the effect of independent variables on serum values of adipokines. The variables that presented $\mathrm{p}<$ 0.20 in the bivariate analysis and/or biological plausibility were included in the multiple linear regression model, which was adjusted for possible confounding factors. The variables were included in the model using the enter method, and those that lost significance were removed $(p<0.05)$. We calculated the confidence interval of $95 \%$ (95).

For the data analysis, we used SPSS ${ }^{\circledR}$ version 21.0 and Stata ${ }^{\circledR}$ version 10.1, at a significance level of $5 \%$ $(p<0.05)$.

\section{RESULTS}

Anthropometric, biochemical, and clinical characteristics of eutrophic and overweight young people

The study sample included 234 young people, classified into two groups: (a) eutrophic children and adolescents (134) and (b) children and adolescents with excess weight (100). The mean age was $10.52 \pm 2.05$ years. Among the students, $52.1 \%$ were female and $66.5 \%$, adolescents. Of those classified as eutrophic, $53.7 \%$ were female, and $68.7 \%$ were adolescents. In relation to the group with excess weight, $50.0 \%$ were female, and $64.0 \%$ were adolescents.

The anthropometric, biochemical, and clinical characteristics of the participants, according to their BMI classification per age, can be found in Table 1. The group with excess weight presented higher values for

TABLE 1. ANTHROPOMETRIC, CLINICAL, AND BIOCHEMICAL VARIABLES CHARACTERIZED BY BMI PER AGE.

\begin{tabular}{|c|c|c|c|c|}
\hline \multirow[t]{2}{*}{ Variables } & \multicolumn{2}{|l|}{ Eutrophy ( $n=134)$} & \multicolumn{2}{|c|}{ Excess weight $(n=100)$} \\
\hline & Mean or median & SD or IQR & Mean or median & SD or IQR \\
\hline Age (years) & 10.69 & 2.02 & 10.41 & 2.1 \\
\hline Height (cm) & 145.4 & 13.54 & 147.67 & 12.95 \\
\hline $\mathrm{WC}(\mathrm{cm})$ & 60.29 & 5.85 & 74.04 & $8.93^{\star \star}$ \\
\hline $\mathrm{BF}(\%)$ & 18.89 & 6.08 & 31.69 & $5.88^{* *}$ \\
\hline $\mathrm{SBP}(\mathrm{mm} \mathrm{Hg})$ & 103.48 & 9.66 & 110.36 & $8.37^{\star \star}$ \\
\hline $\mathrm{DBP}(\mathrm{mm} \mathrm{Hg})$ & 64.15 & 7.05 & 69.39 & $6.15^{\star *}$ \\
\hline Chemerin $(\mathrm{ng} / \mathrm{mL})$ & 220.29 & 103.17 & 213.08 & 119.75 \\
\hline Resistin (pg/mL) & 773.96 & $479.63-1,160.25$ & 942.22 & $606.77-1,461.08^{*}$ \\
\hline Total cholesterol (mg/dL) & 153.0 & $136.0-178.0$ & 160.5 & $144.5-182.25$ \\
\hline $\mathrm{HDL}(\mathrm{mg} / \mathrm{dL})$ & 49.0 & $43.5-57.0$ & 44.0 & $38.75-49.25^{\star *}$ \\
\hline $\mathrm{LDL}(\mathrm{mg} / \mathrm{dL})$ & 94.49 & 25.44 & 99.7 & 23.73 \\
\hline $\mathrm{TG}(\mathrm{mg} / \mathrm{dL})$ & 56.5 & $43.0-79.25$ & 68.5 & $52.0-94.75^{\star \star}$ \\
\hline Serum glucose (mg/dL) & 80.17 & 9.09 & 83.81 & $8.51^{\star \star}$ \\
\hline Fasting insulin $(\mu \mathrm{Ul} / \mathrm{mL})$ & 4.0 & $2.73-6.38$ & 7.3 & $4.35-9.25^{\star *}$ \\
\hline Homa-IR & 0.81 & $0.51-1.35$ & 1.46 & $0.81-2.0^{\star *}$ \\
\hline
\end{tabular}

Note: BMI - body mass index; WC - waist circumference; BF - body fat; SBP - systolic blood pressure; DBP - diastolic blood pressure; LDL - low-density lipoprotein cholesterol; HDL - high-density lipoprotein; TG - triglycerides; Homa-IR, homeostatic model assessment insulin resistance. Data are expressed as mean \pm standard deviation or median (interquartile range) in cases of non-Gaussian data. ${ }^{*} p<0.05 .{ }^{\star *} p<0.01$ 
the following variables: waist circumference, body fat percentage, systolic and diastolic arterial pressure, triglycerides, serum glucose, fasting insulin, and Homa-IR index. On the other hand, they had lower values of HDL-cholesterol, although the values were low in both groups.

The chemerin adipokine presented a reduction in serum values in the group with excess weight [213.08 $\pm 119.75 \mathrm{ng} / \mathrm{mL}$ ] compared to the eutrophic group $[220.29 \pm 103.17 \mathrm{ng} / \mathrm{mL}]$, however, without a significant difference (Figure 1). The opposite profile was observed for resistin values, with $869.35 \pm 515.37 \mathrm{pg} /$ $\mathrm{mL}$ in the eutrophic group and 1,078.31 $\pm 668.49 \mathrm{pg} /$ $\mathrm{mL}$ in the group with excess weight $(\mathrm{p}<0.05)$.

\section{Analysis of correlation and linear regression}

The chemerin adipokine was correlated with diastolic blood pressure and resistin. All correlations were weak and negative. Regarding resistin, we observed a correlation with the values for weight, waist circumference, systolic, and diastolic blood pressure, LDL-c, and chemerin. All correlations proved to be weak and, with the exception of chemerin, were positive.

We included in the multiple linear regression model the variables that presented $p<0.20$ in the bivariate

FIGURE 1. PLASMA LEVELS OF RESISTIN AND CHEMERIN IN EUTROPHIC AND OVERWEIGHT YOUNG INDIVIDUALS.

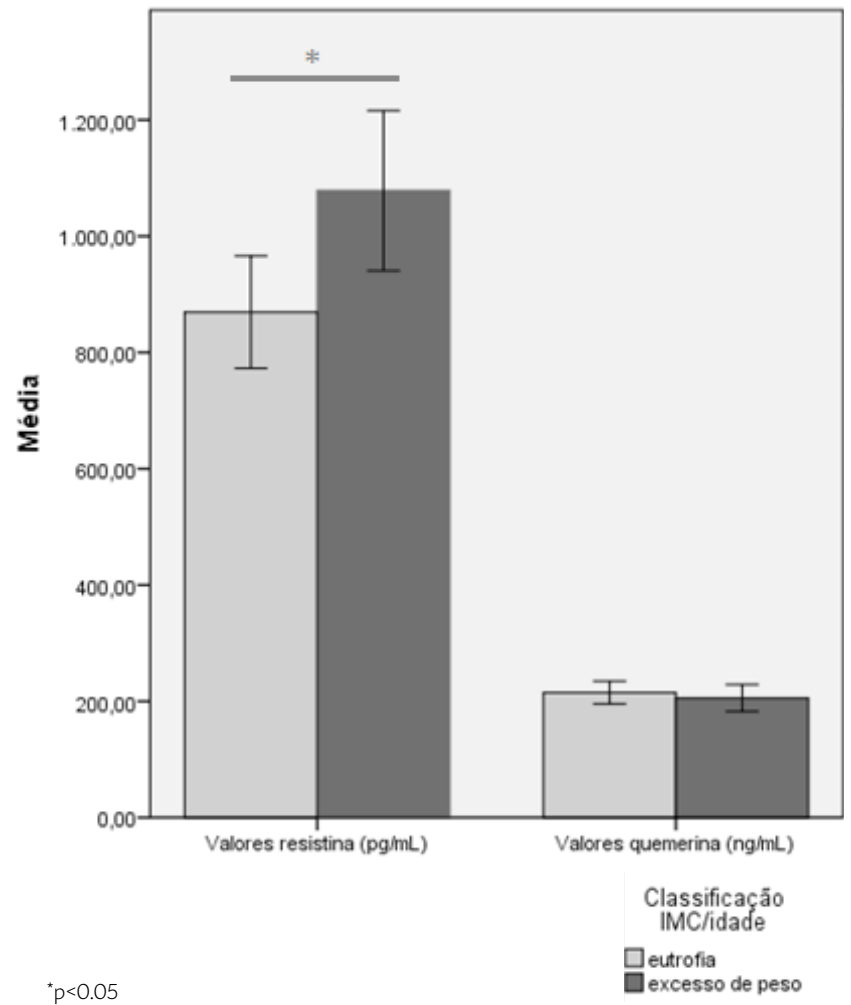

analysis. Thus, in the chemerin model, we included diastolic blood pressure and resistin. Whereas in the model of resistin, we included weight, BMI, waist circumference, body fat percentage, systolic and diastolic arterial pressure, LDL-c, and chemerin. In addition to the parameters that presented $p<0.20$ in the bivariate analysis, variables of biological plausibility were added to the model. Thus, to the chemerin model, we included weight, BMI, waist circumference, systolic blood pressure, and Homa-IR and to the resistin model, BMI, and Homa-IR.

In the multiple linear regression analysis, the values of chemerin showed an association with the resistin values ( $p=0.004,95 \%$ CI: $-0.06-0.01$ ), systolic blood pressure ( $p=0.01,95 \%$ CI: 0.64 - 4.66) and diastolic blood pressure ( $\mathrm{p}=0.001,95 \%$ CI: -7.39 -1.99). The resistin values maintained an association only with the values of BMI ( $p=0.02,95 \%$ CI: 3.52 45.75) and chemerin ( $\mathrm{p}=0.003$, 95\% CI: -1.86 - -0.38). We observed that $8.5 \%$ of the variation of chemerin values could be explained by resistin, systolic and diastolic arterial pressure (Table 2), and $5.8 \%$ of the variation of the resistin concentrations could be explained by BMI and chemerin. The final model is presented in Table 3.

TABLE 2. LINEAR REGRESSION OF ANTHROPOMETRIC, CLINICAL, AND BIOCHEMICAL VARIABLES WITH SERUM VALUES OF CHEMERIN.

\begin{tabular}{|c|c|c|c|}
\hline \multicolumn{4}{|c|}{ Serum concentrations of chemerin } \\
\hline Variables & $\beta$ & Cl 95\% & $P^{*}$ \\
\hline Resistin (pg/mL) & -0.04 & $-0.06--0.01$ & 0.004 \\
\hline $\mathrm{SBP}(\mathrm{mm} \mathrm{Hg})$ & 2.65 & $0.64-4.66$ & 0.01 \\
\hline $\mathrm{DBP}(\mathrm{mm} \mathrm{Hg})$ & -4.69 & $-7.39--1.99$ & 0.001 \\
\hline
\end{tabular}

TABLE 3. LINEAR REGRESSION OF ANTHROPOMETRIC, CLINICAL, AND BIOCHEMICAL VARIABLES WITH SERUM VALUES OF RESISTIN.

\begin{tabular}{|c|c|c|c|}
\hline \multicolumn{4}{|c|}{ Serum concentrations of resistin } \\
\hline Variables & $\beta$ & $\mathrm{Cl} 95 \%$ & $p^{*}$ \\
\hline $\mathrm{BMI}\left(\mathrm{kg} / \mathrm{m}^{2}\right)$ & 24.63 & $3.52-45.75$ & 0.02 \\
\hline Chemerin (ng/mL) & -1.12 & $-1.86--0.38$ & 0.003 \\
\hline
\end{tabular}




\section{DISCUSSION}

In recent years, it has been observed that changes in the adipokine profile may contribute to obesity and several related disorders, such as insulin resistance, hypertension, and CVD. Evidence suggests that the atherosclerotic process begins in childhood, progressing gradually until the onset of clinical manifestations; therefore, early identification of risk factors for CVD is indispensable ${ }^{8}$.

In view of that, the present study evaluated the serum concentrations of two adipokines, which showed a distinct profile in groups of eutrophic and overweight children and adolescents. Resistin presented higher values in individuals with excess weight, while chemerin showed no differences between the groups, with a tendency of reduction in young patients with eutrophic nutritional status. In addition, some traditional risk factors for CVD, such as waist circumference, body fat percentage, systolic and diastolic arterial pressure, triglycerides, serum glucose, fasting insulin, and Homa-IR index, were higher in the group with excess weight when compared to the eutrophic group, as has been observed in several other studies ${ }^{9}$.

Changes in traditional cardiovascular markers can be preceded by changes in the values of adipokines in obese children and adolescents ${ }^{10}$. Higher concentrations of pro-inflammatory adipokines in this population suggest that the inflammatory mechanisms involved in obesity and cardiometabolic complications are already activated ${ }^{\mathbf{1 1}}$. However, there is still insufficient data in the literature to understand the behavior of adipokines in children and adolescents.

Although our findings did not observe any difference between the groups regarding the chemerin, young people with obesity have higher concentrations of this adipokine ${ }^{11}$, with values about $30 \%$ higher than those of eutrophic individuals ${ }^{2}$. Chemerin is a chemoattractive protein that acts regulating the immune response in the process of adipogenesis and glucose metabolism in the liver, skeletal muscle, and adipose tissue $^{12}$. In publications on children and adolescents, serum concentrations of chemerin are associated with obesity, diabetes, risk factors for CVD, and premature vascular inflammation ${ }^{13}$.

We observed a negative correlation between diastolic blood pressure and chemerin values. Unlike what was found in this study, El Dayem et al. ${ }^{14}$ found no correlation between chemerin values and blood pressure. However, Sledzińska et al. ${ }^{15}$ identified a positive correlation between adipokine and systolic blood pressure. However, no explanation was found for this in the literature. The mechanisms of vasoconstriction that can be influenced by chemerin and how they work remain unknown ${ }^{16}$.

In regard to findings on resistin, there is still a contradiction in its association with obesity among children and adolescents ${ }^{\mathbf{1 7}}$. After comparing groups of eutrophic and overweight young people, different behaviors of adipokines were observed. In some studies, it has been observed that resistin values are similar among eutrophic and obese children ${ }^{18}$.

However, like in the present study, Mantovani et al. ${ }^{10}$ and Olza et al. ${ }^{9}$ found higher values of resistin among overweight and obese young individuals. It is known that excess adipose tissue, especially in the abdominal cavities, promotes the secretion of pro-inflammatory adipokines while reducing the synthesis of anti-inflammatory properties ${ }^{9}$.

In another study, by Codoñer-Franch et al. ${ }^{19}$ no differences were found in the concentrations of resistin between eutrophic and obese groups; however, when stratifying them based on the values of insulin resistance, higher serum values of resistin were detected in obese children with insulin resistance in comparison to those who were eutrophic or obese without insulin resistance, which can be explained by the relationship between resistin and the inflammation that is characteristic of obesity and its comorbidities ${ }^{20}$. Resistin is considered a biomarker for insulin resistance, and its association with the Homa-IR index may indicate endothelial damage even in young people since adipokine has effects on vascular cell function?

In the same way, Rupérez et al. ${ }^{21}$ found higher values of resistin between Spanish children with excess weight and those metabolically obese with normal weight.

Resistin is a protein produced in response to inflammatory stimuli ${ }^{20}$ associated with chronic non-communicable diseases, such as obesity, and it may induce insulin resistance and vascular inflammation $^{17.19}$. It is involved in glucose homeostasis, insulin action, and lipid metabolism ${ }^{22}$. The role of adipokine on metabolic syndrome, diabetes mellitus type II, and CVD has been previously described ${ }^{20}$. In the pediatric population, high values of resistin may precede comorbidities associated with obesity ${ }^{10}$.

In this context, our results showed a correlation between the values of resistin and BMI, which was also demonstrated in the study by Lausten-Thomsen et al. ${ }^{17}$. However, other studies have found an association 
of adipokine only with body fat, especially among girls aged between 12 and 16 years ${ }^{23}$, and with the waist circumference, fat mass, and Homa-IR, suggesting it is associated with visceral adiposity ${ }^{18}$. Aeberli et al. ${ }^{24}$ demonstrated that some indexes of adiposity, such as BMI, body fat percentage, and waist circumference, were not considered predictors of resistin.

Regarding the relationship between adipokine and blood glucose and insulin values, Gerber et al. ${ }^{25}$ found no correlation. However, Olza et al. ${ }^{9}$ found a correlation between resistin and the Homa-IR index. In addition, adipokine was positively correlated with inflammatory markers such as IL-6, TNF- $\alpha$, C-reactive protein, and leptin, with an unfavorable lipid profile ${ }^{20}$.

Among the limitations of this study is the relatively small sample size. However, the inclusion criteria were well established, and the assessment protocol was conducted in a rigorous fashion. Furthermore, the study brings as contributions the analysis of adipokines in a population of children and adolescents; it is the first study conducted on this population that seeks to analyze chemerin in Brasil.

Thus, we found that the adipokines analyzed presented a distinct profile in groups of eutrophic overweight children and adolescents and were correlated with some variables traditionally established for assessing CVD risk.

\section{Acknowledgements}

The authors would like to thank the Coordenação de Aperfeiçoamento de Pessoal de Nível Superior (Capes); the Conselho Nacional de Desenvolvimento Científico e Tecnológico (CNPq), and the Fundação de Amparo à Pesquisa do Estado de Minas Gerais (Fapemig - APQ-00957-14). Furthermore, we would like to thank the contributions by the technicians of the laboratories of the Nutrition Department of the Federal University of Juiz de Fora.

\section{RESUMO}

OBJETIVOS: Comparar as concentrações séricas das adipocinas resistina e quemerina em crianças e adolescentes com eutrofia e excesso de peso e avaliar sua relação com as variáveis antropométricas, bioquímicas e a pressão arterial.

MÉTODOS: Estudo epidemiológico transversal realizado com 234 estudantes matriculados em escolas públicas do ensino fundamental no município de Juiz de Fora/MG. Realizou-se avaliação antropométrica, bioquímica e aferição da pressão arterial. As análises estatísticas compreenderam os testes t de Student ou Mann-Whitney, correlação de Pearson ou Spearman, utilizados de acordo com a distribuição das variáveis, e análise de regressão linear, realizada por meio da avaliação do efeito das variáveis independentes nos níveis séricos de quemerina e resistina, ajustado por idade e sexo. Para a análise dos dados foram utilizados os softwares SPSS ${ }^{\circledR}$ versão 21.0 e Stata ${ }^{\circledR}$ versão 10.1, admitindo-se nível de significância de 5\%.

RESULTADOS: As concentrações de quemerina foram maiores nos indivíduos eutróficos do que nos com excesso de peso ( $p>0,05)$. Em contrapartida, os níveis de resistina estiveram maiores nos jovens com excesso ponderal do que nos eutróficos $(p<0,05)$. Na análise de regressão linear múltipla, os níveis de quemerina apresentaram associação com os valores de resistina, pressão arterial sistólica e diastólica. Os níveis de resistina mantiveram associação apenas com os valores de IMC e quemerina.

CONCLUSÃO: As adipocinas analisadas apresentaram perfil distinto nos grupos de crianças e adolescentes com eutrofia e com excesso de peso.

PAlaVRas-ChaVe: Criança. Adolescente. Adipocinas. Fatores de risco. Quimiocinas. Resistina.

\section{REFERENCES}

1. Yamawaki H. Vascular effects of novel adipocytokines: focus on vascular contractility and inflammatory responses. Biol Pharm Bull. 2011;34(3):307-10.

2. Landgraf K, Friebe D, Ullrich T, Kratzsch J, Dittrich K, Herberth G, et al. Chemerin as a mediator between obesity and vascular inflammation in children. J Clin Endocrinol Metab. 2012;97(4):E556-64.

3. Martins LM, Oliveira ARS, Cruz KJC, Torres-Leal FL, Marreiro DN. Obesity, inflammation, and insulin resistance. Braz J Pharm Sci. 2014;50(4):677-92.

4. Gomes F, Telo DF, Souza HP, Nicolau JC, Halpern A, Serrano CV Jr. Obesity and coronary artery disease: role of vascular inflammation. Arq Bras Cardiol. 2010;94(2):255-6, 273-9, 260-6.

5. Hung AM, Sundell MB, Egbert P, Siew ED, Shintani A, Ellis CD, et al. A comparison of novel and commonly-used indices of insulin sensitivity in African American chronic hemodialysis patients. Clin f Am Soc Nephrol. 2011;6(4):767-74
6. Skinner AC, Steiner MJ, Henderson FW, Perrin EM. Multiple markers of inflammation and weight status: cross-sectional analyses throughout childhood. Pediatrics. 2010;125(4):e801-9.

7. Deurenberg P, Weststrate |A, Seidell IC. Body mass index as a measure of body fatness: age- and sex-specific prediction formulas. $\mathrm{Br}$ J Nutr. 1991;65(2):105-14.

8. Wang Z, Nakayama T. Inflammation, a link between obesity and cardiovascular disease. Mediators Inflamm. 2010;2010:535918.

9. Olza J, Aguilera CM, Gil-Campos M, Leis R, Bueno G, Valle M, et al. Waistto-height ratio, inflammation and CVD risk in obese children. Public Health Nutr. 2014;17(10):2378-85.

10. Mantovani RM, Rocha NP, Magalhães DM, Barbosa IG, Teixeira AL, Simões $E$, et al. Early changes in adipokines from overweight to obesity in children and adolescents. J Pediatr (Rio J). 2016;92(6):624-30. 
11. Schipper HS, Nuboer R, Prop S, van den Ham HJ, de Boer FK, Kesmir Ç, et al. Systemic inflammation in childhood obesity: circulating inflammatory mediators and activated CD14++ monocytes. Diabetologia. 2012;55(10):2800-10.

12. Verrijn Stuart AA, Schipper HS, Tasdelen I, Egan DA, Prakken BJ, Kalkhoven $E$, et al. Altered plasma adipokine levels and in vitro adipocyte differentiation in pediatric type 1 diabetes. J Clin Endocrinol Metab. 2012;97(2):463-72.

13. Fontes VS, Neves FS, Cândido APC. Chemerin and factors related to cardiovascular risk in children and adolescents: a systematic review. Rev Paul Pediatr. 2018;36(2):221-9.

14. El Dayem SM, Battah AA, El Bohy Ael M, El Shehaby A, El Ghaffar EA. Relationship of plasma level of chemerin and vaspin to early atherosclerotic changes and cardiac autonomic neuropathy in adolescent type 1 diabetic patients. J Pediatr Endocrinol Metab. 2015;28(3-4):265-73.

15. Sledzińska M, Szlagatys-Sidorkiewicz A, Brzezinski M, Kaźmierska K Sledziński T, Kamińska B. Serum chemerin in children with excess body weight may be associated with ongoing metabolic complications: a pilot study. Adv Med Sci. 2017;62(2):383-6.

16. Bozaoglu K, Curran JE, Stocker C), Zaibi MS, Segal D, Konstantopoulos N, et al. Chemerin, a novel adipokine in the regulation of angiogenesis. I Clin Endocrinol Metab. 2010;95(5):2476-85.

17. Lausten-Thomsen $U$, Christiansen $M$, Hedley PL, Nielsen TRH, Fonvig CE, Pedersen $\mathrm{O}$, et al. Reference values for fasting serum resistin in healthy children and adolescents. Clin Chim Acta. 2017;469:161-5.

18. Ding W, Cheng H, Chen F, Yan Y, Zhang M, Zhao X. Adipokines are associated with hypertension in Metabolically Healthy Obese $(\mathrm{MHO})$ children and adolescents: a prospective population-based cohort study. J Epidemiol. 2018;28(1):19-26.
19. Codoñer-Franch P, Tavárez-Alonso S, Porcar-Almela M, Navarro-Solera M Arilla-Codoñer Á, Alonso-Iglesias E. Plasma resistin levels are associated with homocysteine, endothelial activation, and nitrosative stress in obese youths. Clin Biochem. 2014;47(1-2):44-8.

20. Nascimento H, Vieira E, Coimbra S, Catarino C, Costa E, Bronzeda-Rocha E, et al. Adipokine gene single-nucleotide polymorphisms in Portuguese obese adolescents: associations with plasma concentrations of adiponectin, resistin, IL-6, IL-1 $\beta$, and TNF- $\alpha$. Child Obes. 2016;12(4):300-13.

21. Rupérez Al, Olza J, Gil-Campos M, Leis R, Bueno G, Aguilera CM, et al. Cardiovascular risk biomarkers and metabolically unhealthy status in prepubertal children: comparison of definitions. Nutr Metab Cardiovasc Dis. 2018;28(5):524-30.

22. García-Hermoso A, Ceballos-Ceballos RJ, Poblete-Aro CE, Hackney AC, Mota J, Ramírez-Vélez R. Exercise, adipokines and pediatric obesity: a meta-analysis of randomized controlled trials. Int | Obes (Lond). 2017;41(4):475-82

23. Ortega L, Riestra P, Navarro P, Gavela-Pérez T, Soriano-Guillén L, Garcés C. Resistin levels are related to fat mass, but not to body mass index in children. Peptides. 2013;49:49-52.

24. Aeberli I, Spinas GA, Lehmann R, I'Allemand D, Molinari L, Zimmermann MB. Diet determines features of the metabolic syndrome in 6- to 14-yearold children. Int J Vitam Nutr Res. 2009;79(1):14-23.

25. Gerber M, Boettner A, Seidel B, Lammert A, Bär J, Schuster E, et al. Serum resistin levels of obese and lean children and adolescents: biochemical analysis and clinical relevance. I Clin Endocrinol Metab. 2005;90(8):4503-9. 